\title{
Covid-19: PHE upgrades PPE advice for all patient contacts with risk of infection
}

\author{
Anna Sayburn \\ London
}

New guidelines on use of personal protective equipment (PPE) by healthcare workers significantly expands the potential use of eye protection and fluid resistant surgical masks, including to doctors carrying out face-to-face assessments where a patient's risk of covid-19 is unknown. ${ }^{1}$

The updated guidance from Public Health England, which is in line with World Health Organization recommendations, allows for local risk assessment in hospitals and primary care. GPs, staff in emergency or acute admissions units, and others who assess or treat patients without high risk symptoms but in areas of high transmission of covid-19 should wear aprons, surgical masks, eye protection, and gloves where the risk of droplet transmission is thought to warrant it (table 1).

This change "reflects the fact that coronavirus is now widespread in the community," and so doctors are more likely to see patients infected with the virus who may not have symptoms, Public Health England said in a statement. ${ }^{2}$

The guidance emphasises, "Ultimately, where staff consider there is a risk to themselves or the individuals they are caring for they should wear a fluid repellent surgical mask with or without eye protection, as determined by the individual staff member for the episode of care or single session."

Clinicians who perform aerosol generating procedures on patients with suspected or confirmed covid-19 are advised to wear full face shields or visors, not just eye protection. These protections can also be used when the covid-19 status is unknown, according to local risk assessment

The guidance also says that masks, eye protection, and gowns can be used for a "session" of work, such as a ward round, rather than needing to be changed for each patient contact. It does not specify the length of a session. The guidance says that "there is no evidence to show that discarding disposable respirators, facemasks or eye protection in between each patient reduces the risk of infection transmission" and suggests that continual donning and doffing of PPE could increase exposure.

In a statement Public Health England said, "The guidance is based on the best scientific evidence and the WHO have confirmed it is consistent with what it recommends in circumstances and settings with the highest risk of transmission." ${ }^{2}$

The guidance has been welcomed by professional bodies, although the BMA warns that lack of provision remains acute. Its chair of council, Chaand Nagpaul, said, "Although Public Health England has produced updated guidance, what fundamentally matters is that doctors and healthcare workers get the adequate and appropriate supplies of PPE on the frontline. Without these supplies there is continued unacceptable danger to the health and lives of healthcare workers and their patients."

Nagpaul said that the BMA had heard from doctors in 30 NHS hospitals and GPs across the UK that they had insufficient or no stocks of PPE.

Martin Marshall, chair of the Royal College of General Practitioners, welcomed "much needed clarity" in the guidelines but added, "We understand that initial stocks of PPE have been getting to GP practices. We now need to ensure that this supply is sustained throughout the pandemic, that practices start receiving new equipment recommended in the guidance such as eye protection soon, and that effective mechanisms are in place for practices to request emergency supplies, should they need them."

Niall Dickson, chief executive of the NHS Confederation, described the revised guidance as "an important step towards rebuilding trust." He said, "We cannot underestimate the loss of confidence among key frontline staff on this issue."

The list of aerosol generating procedures has not changed from last week, although an evidence review of this is under way and may lead to changes in guidance. ${ }^{3}$

Types of personal protective equipment

- FFP3 (filtering facepiece) respirators filter at least $99 \%$ of airborne particles

- FFP2 and N95 respirators filter $94 \%$ and $95 \%$ of particles and may be used if FFP3 respirators are not available

- Fluid resistant surgical masks (type IIR) provide barrier protection against droplets

- Eye and face protection can be a fluid resistant surgical mask with integrated visor, full face shield or visor, or polycarbonate safety spectacles

- Long sleeved, disposable, fluid repellent gowns must be worn "when a disposable plastic apron provides inadequate cover of staff uniform or clothes for the procedure or task being performed" and when there is "a risk of splashing of body fluids"

- If non-fluid resistant gowns are used, a disposable plastic apron should be worn underneath

1 Public Health England. COVID-19 personal protective equipment (PPE). 2 Apr 2020 https://www.gov.uk/government/publications/wuhan-novel-coronavirus-infection-preventionand-control/covid-19-personal-protective-equipment-ppe. 
2 Public Health England. New PPE guidance for NHS teams [press release]. 2 Apr 2020. https://www.gov.uk/government/news/new-personal-protective-equipment-ppe-guidancefor-nhs-teams.

3 Health Protection Scotland. Aerosol generating procedures (AGPs) [literature review]. 2 Apr 2020. https://hpspubsrepo.blob.core.windows.net/hps-website/nss/2893/documents/ 1_tbp-Ir-agp-v1.pdf
Published by the BMJ Publishing Group Limited. For permission to use (where not already granted under a licence) please go to http://group.bmj.com/group/rights-licensing/ permissions 


\section{Table}

\section{Table 1] What should you use when?}

\section{Situation}

Performing AGPs on patient with suspected or confirmed covid-19 OR all patients in context of sustained covid-19 transmission of covid-19 cannot be established before the consultation

\begin{tabular}{|c|c|c|c|c|}
\hline $\begin{array}{l}\text { Within higher risk acute inpatient care areas (where } \\
\text { AGPs are regularly performed) }\end{array}$ & FFP3 respirator & $\begin{array}{l}\text { Long sleeved, disposable, fluid } \\
\text { repellent gown (with } \\
\text { disposable plastic apron } \\
\text { underneath if only a non-fluid } \\
\text { resistant gown is available) }\end{array}$ & Eye protection & Disposable gloves \\
\hline $\begin{array}{l}\text { Inpatient area with suspected or confirmed covid- } 19 \\
\text { patients (not giving care) }\end{array}$ & Fluid resistant surgical mask & Not applicable & Not applicable & Not applicable \\
\hline $\begin{array}{l}\text { Inpatient area with suspected or confirmed covid-19 } \\
\text { patients (giving direct care) }\end{array}$ & Fluid resistant surgical mask & Apron & Eye protection & Disposable gloves \\
\hline $\begin{array}{l}\text { Inpatient areas with no identified suspected or } \\
\text { confirmed cases }\end{array}$ & Local risk assessment & Local risk assessment & Local risk assessment & Local risk assessment \\
\hline $\begin{array}{l}\text { Emergency or acute admissions, possible or } \\
\text { confirmed cases (or all cases subject to local risk } \\
\text { assessment) }\end{array}$ & Fluid resistant surgical mask & Apron & Eye protection & Disposable gloves \\
\hline Transfer of possible or confirmed cases & Fluid resistant surgical mask & Apron & Local risk assessment & Disposable gloves \\
\hline $\begin{array}{l}\text { Operating theatres without AGPs, treatment of } \\
\text { possible or confirmed cases (or all patients subject } \\
\text { to local risk assessment) }\end{array}$ & Fluid resistant surgical mask & Local risk assessment & Eye protection & Standard IPC procedure \\
\hline $\begin{array}{l}\text { Labour ward (not AGPs or surgery) for possible or } \\
\text { confirmed cases (or all patients subject to local risk } \\
\text { assessment) }\end{array}$ & Fluid resistant surgical mask & $\begin{array}{l}\text { Long sleeved, disposable, fluid } \\
\text { repellent gown, apron }\end{array}$ & Eye protection & Disposable gloves \\
\hline $\begin{array}{l}\text { Primary care, direct care of possible or confirmed } \\
\text { case (or all patients subject to local risk assessment) }\end{array}$ & Fluid resistant surgical mask & Apron & Eye protection & Disposable gloves \\
\hline
\end{tabular}

\begin{tabular}{cccc} 
Mask or respirator & Apron or gown & Eye protection & Gloves \\
\hline FFP3 respirator & $\begin{array}{c}\text { Long sleeved, disposable, fluid } \\
\text { repellent gown }\end{array}$ & Full face shield or visor & Disposable gloves
\end{tabular}

Apron Eye protection Disposable gloves

AGPS=aerosol generating procedures 